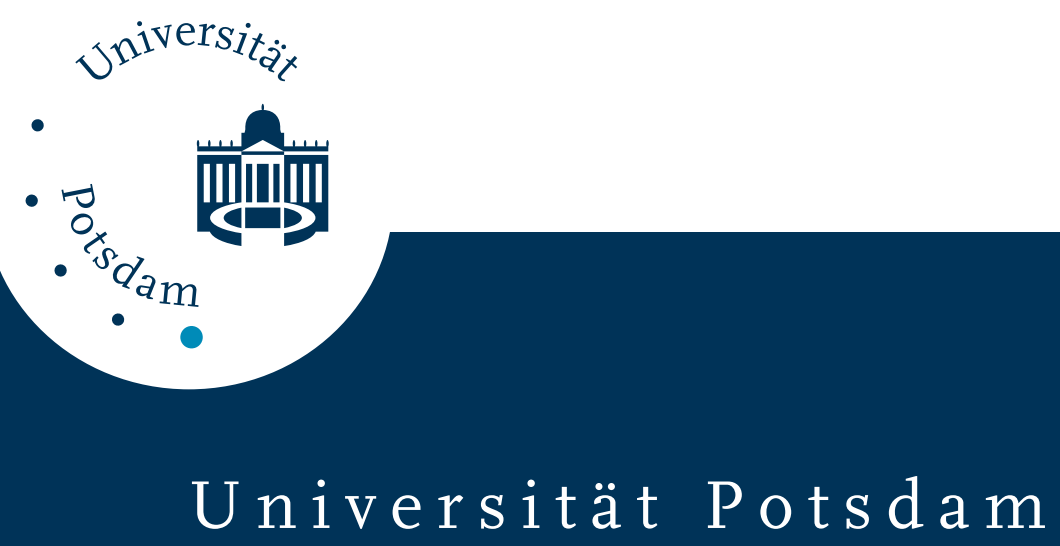

Monika Wulf, Thilo Heinken

\title{
Colonization of recent coniferous versus deciduous forest stands by vascular plants at the local scale
}

first published in:

Applied vegetation science. - 11 (2008), 3, S. 307 - 316,

DOI: $10.3170 / 2008-7-18432$

Postprint published at the Institutional Repository of the Potsdam University:

In: Postprints der Universität Potsdam

Mathematisch-Naturwissenschaftliche Reihe ; 149

http://opus.kobv.de/ubp/volltexte/2010/4608/

http://nbn-resolving.de/urn:nbn:de:kobv:517-opus-46080

Postprints der Universität Potsdam

Mathematisch-Naturwissenschaftliche Reihe ; 149 



\title{
Colonization of recent coniferous versus deciduous forest stands by vascular plants at the local scale
}

\author{
Wulf, Monika $^{*}$ \& Heinken, Thilo ${ }^{2}$ \\ ${ }^{1}$ Leibniz Centre for Agricultural Research (ZALF e.V.), Institute of Land Use Systems and Landscape Ecology, \\ Eberswalder Straße 84, DE-15374 Müncheberg, Germany; \\ ${ }^{2}$ Institute of Biochemistry and Biology, Community Ecology/Systematic Botany, University of Potsdam, Maulbeerallee 1, \\ DE-14469 Potsdam, Germany; E-mail heinken@uni-potsdam.de; \\ ${ }^{*}$ Corresponding author; Fax +49 3343282387; E-mail mwulf@zalf.de
}

\begin{abstract}
Questions: 1. Are there differences among species in their preference for coniferous vs. deciduous forest? 2. Are tree and shrub species better colonizers of recent forest stands than herbaceous species? 3. Do colonization patterns of plant species groups depend on tree species composition?

Location: Three deciduous and one coniferous recent forest areas in Brandenburg, NE Germany.

Methods: In 34 and 21 transects in coniferous and deciduous stands, respectively, we studied the occurrence and percentage cover of vascular plants in a total of 150 plots in ancient stands, 315 in recent stands and 55 at the ecotone. Habitat preference, diaspore weight, generative dispersal potential and clonal extension were used to explain mechanisms of local migration. Regression analysis was conducted to test whether migration distance was related to species' life-history traits.

Results: 25 species were significantly associated with ancient stands and ten species were significantly more frequent in recent stands. Tree and shrub species were good colonizers of recent coniferous and deciduous stands. In the coniferous stands, all herbaceous species showed a strong dispersal limitation during colonization, whereas in the deciduous stands generalist species may have survived in the grasslands which were present prior to afforestation.

Conclusions: The fast colonization of recent stands by trees and shrubs can be explained by their effective dispersal via wind and animals. This, and the comparably efficient migration of herbaceous forest specialists into recent coniferous stands, implies that the conversion of coniferous into deciduous stands adjacent to ancient deciduous forests is promising even without planting of trees.
\end{abstract}

Keywords: Clonal growth; Diaspore weight; Dispersal potential; Forest specialist; Generalist emergent group.

Nomenclature: Wisskirchen \& Haeupler (1998).

\section{Introduction}

Two major trends have changed the forest area and tree species composition in the central European landscape during the last 250 years. First, wooded areas were expanded either by afforestation or spontaneous regeneration (Mather 2000). In the 19th century, sandy soils of the plains (often former heathland) were afforested mainly with Pinus sylvestris, whereas in the 20th century preferably moist lowlands were afforested with Alnus glutinosa or Populus spp. (Hermy \& Stieperaere 1981). Second, many deciduous forests were converted to coniferous forests (Ewald 2000). With increasing interest in sustainable forestry the conversion of evenaged coniferous stands into mixed or pure broad-leaved stands has been promoted over the last 10 to 15 years (Nyland 2003). Ancient deciduous forests (= forested areas for at least 200 years) are known to be richer in true forest herbaceous species than forests established on former agricultural land (= recent forests), and many plant species show a strong affinity to the former of these habitats (Hermy et al. 1999; Wulf 2003).

Comparative studies of the flora of ancient and recent coniferous forests have not been carried out to date, but from Nagaike et al. (2005) we know that the conversion of ancient deciduous stands into coniferous stands does not necessarily lead to a loss in herbaceous forest species. Several studies have shown that true forest species with adaptations for long-distance dispersal are better colonizers of recent stands adjacent to ancient stands than those without. Herbaceous species often show a marked and rapid decrease, both in terms of number and abundance, with increasing distance to the adjacent ancient stands (Verheyen et al. 2003). However, all previous studies (but see Dzwonko 2001) focussed exclusively on deciduous recent stands which is quite surprising given the large extent of recent coniferous stands in present-day European landscapes. Moreover, previous studies excluded tree and shrub species in the herb layer (i.e. seedlings and saplings) and focussed on single species instead of species groups. 
Grouping of species according to their life history traits (e.g. dispersal potential) may be useful to predict the vegetation dynamics (Honnay et al. 1999), and to identify general patterns in the colonization of recent stands.

The thickness of the litter layer and acidification both hamper recruitment and growth of typical deciduous forest species (e.g. Eriksson 1995). Since litter of evergreen species accumulates over the years and produces organic acids (Augusto et al. 1998), one could expect that some species are unable to colonize recent coniferous forests or that migration is at least significantly delayed in comparison with colonization processes in deciduous forests. However, Dzwonko (2001) found several forest species in recent coniferous stands on limestone.

The objective of this study is to examine the ability of various species groups to colonize recent stands of different tree species composition and to analyse whether particular species traits, such as life history and habitat preference, can be used to explain patterns of migration into recent coniferous and deciduous stands. Such investigations are essential for understanding distribution patterns of plants on the local scale and for making suggestions for a future forest management that also takes nature conservation aspects into account. More specifically, we addressed the following questions:

1. Are there differences among species in their preference for coniferous vs. deciduous stands?

2. Are tree and shrub species better colonizers of recent forest stands than herbaceous species?

3. Do colonization patterns of plant species groups depend on tree species composition?

\section{Methods}

\section{Study sites}

We analysed colonization patterns of deciduous recent stands in three forests, and of coniferous recent stands in one forest (Table 1) in the Federal State of Brandenburg in NE Germany. In all ancient sites only a few trees have been logged over several decades. The adjacent deciduous recent stands were former grassland. The coniferous recent stands are located within a large deciduous forest area and have undergone ploughing and tilling after clearing of the preceding forest stand (Table 1). It is not a recent stand in the strict sense, but the measures prior to afforestation completely destroyed the herb layer, notably the use as an arable field. To simplify matters we used the term 'recent'.

The mean annual temperature of the study region is $8-9^{\circ} \mathrm{C}$ (January: $-1-0^{\circ} \mathrm{C}$, July: $18^{\circ} \mathrm{C}$ ) and the mean annual precipitation varies between $500 \mathrm{~mm}$ and $650 \mathrm{~mm}$. Prevalent geological substrates are ground moraines from the Saale and Weichsel glaciation consisting of sand and loam, and fluvial sand deposits. The investigated forests grow mainly on fresh to moist, mesotrophic to eutrophic soils. Soil types can be designated as eutric cambisols, haplic stagnosols and haplic gleysols (Anon. 1998).

Zonal vegetation is dominated by Fagus sylvatica and Quercus petraea and Q. robur. Woodland communities on meso- or eutrophic, mostly moist soils (Fagion, Carpinion, Alno-Ulmion) are frequent (Hofmann \& Pommer 2004). All ancient stands of our study sites, with varying proportions of mainly F. sylvatica, Fraxinus excelsior and Q. robur (Table 1) and a species-rich herb layer, belong to the Stellario holosteae-Carpinetum (Carpinion) (ShC) and to the Stellario nemori-Alnetum (Alno-Ulmion) (SnA). The treelayer of the deciduous recent stands mainly consists of Alnus glutinosa and F. excelsior (ShC/SnA) and the coniferous recent stands are exclusively Pinus sylvestris stands (Table 1). To identify recent stands adjoining ancient stands we comparedhistorical maps (from 1780 and 1880) with actual maps (from 1980, all maps at scale $1: 50000$ ). Information on the exact year of origin of the recent stands and on further characteristics of the stands, including former use of the recent stands, was compiled from documents of the local forest service.

\section{Data collection}

In spring and summer 2001 and 2002 we investigated 34 and 21 transects in coniferous and deciduous recent stands, respectively. Each transect was laid perpendicular to the boundary between the ancient and the recent stand, and crossed the boundary. Length of transects in the recent stands varied between $22 \mathrm{~m}$ and $87 \mathrm{~m}$ (Table 1), and there was a distance of at least $10 \mathrm{~m}$ between the transects. Transect length in the ancient stands varied between $6 \mathrm{~m}$ and $28 \mathrm{~m}$. Number and length of transects depended on the size of recent stands and the area with similar site conditions. Along each transect, we placed $3 \mathrm{~m} \times 3 \mathrm{~m}$ sampling plots at distances of $3 \mathrm{~m}$. In some deciduous stands distances varied between $1.5 \mathrm{~m}$ and $10 \mathrm{~m}$ to avoid some disturbed areas in the herb layer caused by wild boars. Canopy cover was similar among the recent stands (Table 1).

To achieve comparability between recent stands of different age we calculated standardized distances for each plot by dividing the distance to the ancient stands by the age of the recent stands (Bossuyt et al. 1999). In total, we sampled 520 plots ( 114 in the ancient coniferous and 36 in the ancient deciduous stands as well as 189 in the recent coniferous and 126 in the recent deciduous stands, respectively, and 55 at the ecotone). In each plot we estimated the cover of all vascular plants in the herb layer to the nearest percent from $1 \%-5 \%$ and to the nearest 5\% from $10 \%-100 \%$ cover. 
Species groups

To investigate the mechanisms of local migration we grouped species according to their habitat preference and some life history traits and tested whether these species groups differed in their colonization abilities. For the classification of herb layer species into forest specialists (plant species closely tied to forests including forest clearings and fringes) and generalists (species growing in the forest as well as in open vegetation) we used the list of Schmidt et al. (2003). Few species which were not listed (species of open vegetation) were also included in the generalists (App. 1).

We selected three species traits (diaspore weight, dispersal potential and clonal extension), which we expected to be related most to the distribution patterns along transects in recent stands. To obtain sufficient data in all species groups and a similar number of species in the groups we created two subgroups for each trait, corresponding to low and high values. Dispersal potentials were mainly derived from diaspore morphology; they were substantially improved by recent knowledge on influence of exposition height and terminal velocity on wind dispersal distances and on regional dispersal processes by animals (App. 2). We checked inter-correlations between all species groups, but only seed weight and dispersal potential showed a relatively weak negative, but significant correlation (Kendall's $\tau=-0.25, p=$ $0.005)$.

\section{Data analysis}

Preferences of species for ancient or recent stands (ecotones excluded) and ancient, deciduous parts of both transect groups, respectively, were checked with an online Fisher's exact probability test (http://graphpad.com/quickcalcs/contingency1.cfm). Only species occurring in at least five plots were considered. A linear regression analysis was conducted to test whether colonization patterns are related to species traits. For this, we first calculated mean cover values of species of the different trait subgroups (low and high values) and then regressed the means on the standardized distances. For this analysis we used data from the ecotone and the recent stand plots. According to our second and third questions we checked whether some species groups show steeper slopes than others in both forest types, and whether certain species groups always show steeper slopes within the coniferous stands than within the deciduous stands. Since normal distribution of the slope values cannot be achieved via transformation we applied the Mann-Whitney $U$-test to compare species groups and trait-based groups. All statistical tests were carried out with SPSS 12.0 (Anon. 2003).

Table 1. Characteristics of studied forests and transect groups: dominant tree species: $\mathrm{Ag}=$ Alnus glutinosa, Fe $=$ Fraxinus excelsior, $\mathrm{Fs}=$ Fagus sylvatica, $\mathrm{Bv}=$ Betula pendula, $\mathrm{U}=$ Ulmus, $\mathrm{Cb}=$ Carpinus betulus, $\mathrm{T}=$ Tilia, $\mathrm{Q}=$ Quercus, and $\mathrm{Ps}=$ Pinus sylvestris. $\mathrm{CC}=$ canopy cover, and site conditions according to forestry inventory $(\mathrm{K}, \mathrm{R}=$ high and very high nutrient level; $\mathrm{N}=$ wet sites; 1, 2 and 3: moist, fresh and dry sites), humus type ( $\mathrm{fMu}=$ humid mull, $\mathrm{fMM}=$ humid, mull-like leafmould, iMo = relatively fresh leafmould).

\begin{tabular}{|c|c|c|c|c|c|c|c|c|c|c|}
\hline Study & Lat. & Long & $\begin{array}{l}\text { Age } \\
\text { (a) } \\
\text {. }\end{array}$ & $\begin{array}{c}\text { Dominant } \\
\text { area } \\
\text { (ha) }\end{array}$ & $\begin{array}{c}\text { Tree species } \\
\text { anc / rec }\end{array}$ & $\mathrm{CC}$ & $\begin{array}{c}\text { Site } \\
\text { conditions }\end{array}$ & $\begin{array}{l}\text { Humus } \\
\text { type }\end{array}$ & $\begin{array}{c}\text { Former } \\
\text { use } \\
\text { (duration) }\end{array}$ & $\begin{array}{l}\text { asect length } \\
\text { wood }(\mathrm{m}) \\
\text { of transects) }\end{array}$ \\
\hline \multicolumn{11}{|l|}{ Coniferous } \\
\hline Bredow 1 & $52^{\circ} 36^{\prime} \mathrm{N}$ & $13^{\circ} 01^{\prime} \mathrm{E}$ & $30)$ & \multirow{3}{*}{650} & $\mathrm{Bv}, \mathrm{E}, \mathrm{Q} / \mathrm{P}$ & 1.0 & NR3 & $\mathrm{fMu} / \mathrm{fMM}$ & \multirow{3}{*}{$\begin{array}{l}\text { Ploughing and } \\
\text { tilling after } \\
\text { deforestation }\end{array}$} & $22-34(13)$ \\
\hline Bredow 2 & $52^{\circ} 36^{\prime} \mathrm{N}$ & $13^{\circ} 01^{\prime} \mathrm{E}$ & 30 & & $\mathrm{Bv}, \mathrm{C}, \mathrm{Q} / \mathrm{P}$ & 1.0 & NR3 & $\mathrm{fMu} / \mathrm{fMM}$ & & $34(9)$ \\
\hline Bredow 3 & $52^{\circ} 36^{\prime} \mathrm{N}$ & $13^{\circ} 01^{\prime} \mathrm{E}$ & $30 J$ & & $\mathrm{Bv}, \mathrm{T}, \mathrm{Q} / \mathrm{P}$ & 1.0 & NR3 & $\mathrm{fMu} / \mathrm{fMM}$ & & $22-34(12)$ \\
\hline \multicolumn{11}{|l|}{ Deciduous } \\
\hline Gadow 1 & $53^{\circ} 04^{\prime} \mathrm{N}$ & $11^{\circ} 39^{\prime} \mathrm{E}$ & $36)$ & \multirow{3}{*}{ ca. 3000} & $\mathrm{Fe}, \mathrm{Fs} / \mathrm{Ag}, \mathrm{Fe}$ & $1.0-1.3$ & NK2 & $\mathrm{fMu}$ & Meadow (> $100 \mathrm{a})$ & $39(2)$ \\
\hline Gadow 2 & $53^{\circ} 04^{\prime} \mathrm{N}$ & $11^{\circ} 39^{\prime} \mathrm{E}$ & $40\}$ & & $\mathrm{Fe}, \mathrm{Fs} / \mathrm{Ag}, \mathrm{Fe}$ & 1.2 & NR1/NK2 & $\mathrm{fMu}$ & Meadow (> 100 a) & $87(4)$ \\
\hline Gadow 3 & $53^{\circ} 04^{\prime} \mathrm{N}$ & $11^{\circ} 39^{\prime} \mathrm{E}$ & 61 J & & $\mathrm{Fe}, \mathrm{Fs}, \mathrm{Q} / \mathrm{Ag}, \mathrm{Fe}$ & $0.9-1.2$ & NR1 & $\mathrm{fMu}$ & Pasture (> 100 a) & $34-52(5)$ \\
\hline Krampfer & $53^{\circ} 03^{\prime} \mathrm{N}$ & $12^{\circ} 01^{\prime} \mathrm{E}$ & 62 & 31 & $\mathrm{Fs}, \mathrm{Q} / \mathrm{Ag}, \mathrm{Q}$ & $1.0-1.3$ & $\mathrm{NR} 2 / \mathrm{K} 2$ & $\mathrm{fMu} / \mathrm{iMo}$ & Meadow (> $100 \mathrm{a})$ & $52(3)$ \\
\hline Wittstock 1 & $53^{\circ} 15^{\prime} \mathrm{N}$ & $12^{\circ} 30^{\prime} \mathrm{E}$ & $47)$ & \multirow{3}{*}{ ca. 6000} & $\mathrm{As}, \mathrm{Fs}, \mathrm{Q} / \mathrm{Ag}, \mathrm{Fe}$ & $0.9-1.4$ & $\mathrm{NR} 2$ & $\mathrm{fMu}$ & Meadow (> 100 a) & $52-61(3)$ \\
\hline Wittstock 2 & $53^{\circ} 15^{\prime} \mathrm{N}$ & $12^{\circ} 30^{\prime} \mathrm{E}$ & 66 & & $\mathrm{As}, \mathrm{Fs}, \mathrm{Q} / \mathrm{Ag}, \mathrm{Fe}$ & $1.2-1.5$ & NR2 & $\mathrm{fMu}$ & Meadow(> 100 a) & $52(1)$ \\
\hline Wittstock 3 & $53^{\circ} 15^{\prime} \mathrm{N}$ & $12^{\circ} 30^{\prime} \mathrm{E}$ & 93 & & $\mathrm{As}, \mathrm{Fs}, \mathrm{Q} / \mathrm{Ag}, \mathrm{Fe}$ & 0.8 & NR2 & $\mathrm{fMu}$ & Meadow (80-90 a) & $52(3)$ \\
\hline
\end{tabular}




\section{Results}

\section{Preference of species for contrasting stands}

Of the 76 plant species 25 (34\%) were significantly more frequent in the ancient stands compared to recent stands (Fisher's test, $p<0.05$ ) and ten species $(13 \%)$ were significantly more frequent in the recent stands (Table 2). Only three of the 20 tree/shrub species (15\%), but 22 of the 54 herbaceous species $(41 \%)$ were significantly associated with ancient stands. Whereas 21 species were significantly more frequent in ancient stands compared to coniferous recent stands, this was only true for three species when comparing ancient to deciduous recent stands. Of the ten species with preference for recent stands, six occurred only in the coniferous recent stands and four only in the deciduous recent stands. Differences between the ancient, deciduous parts of the two plot groups were also pronounced (Table 2). Eight species, among them many seedlings and saplings of trees and shrubs, were significantly more frequent in the coniferous recent stands, whereas 14 species, especially indicators of wet and base-rich soils, were more frequent in the deciduous recent stands.

Table 2. Frequencies of species in ancient (Anc, $N=150$ ) and recent (Rec, $N=315$ ) plots as well as in coniferous $(\mathrm{C}, \mathrm{N}=337$ incl. ecotone plots) and deciduous ( $\mathrm{D}, \mathrm{N}=173$ incl. ecotone plots) plots: differences between pairs were tested with Fisher's exact probability test. Frame: significant results $(p<0.05)$ when comparing (1) ancient vs. recent forests and (2) ancient forests adjacent to either coniferous or deciduous recent forests (C*vs. D Anc). $N=$ total number of occurrences ( 477 plots). $\mathrm{h}=$ species of the herb layer, $\mathrm{s}=$ shrub species, $\mathrm{t}=$ tree species. Only species with at least five occurrences are listed. $\mathrm{C}^{*}=$ ancient plots adjacent to coniferous transects are composed of deciduous trees.

\begin{tabular}{|c|c|c|c|c|c|}
\hline Forest type & $\mathrm{C}^{*}$ & $\mathrm{C}$ & $\mathrm{D}$ & $\mathrm{D}$ & $N$ \\
\hline Forest age & Anc & Rec & Anc & $\operatorname{Rec}$ & \\
\hline Number of plots & 114 & 189 & 36 & 126 & \\
\hline Mean number of tree and shrub species & 3.1 & 3.4 & 1.2 & 1.1 & \\
\hline Mean number of herbaceous species & 6.4 & 3.7 & 8.6 & 9.5 & \\
\hline
\end{tabular}

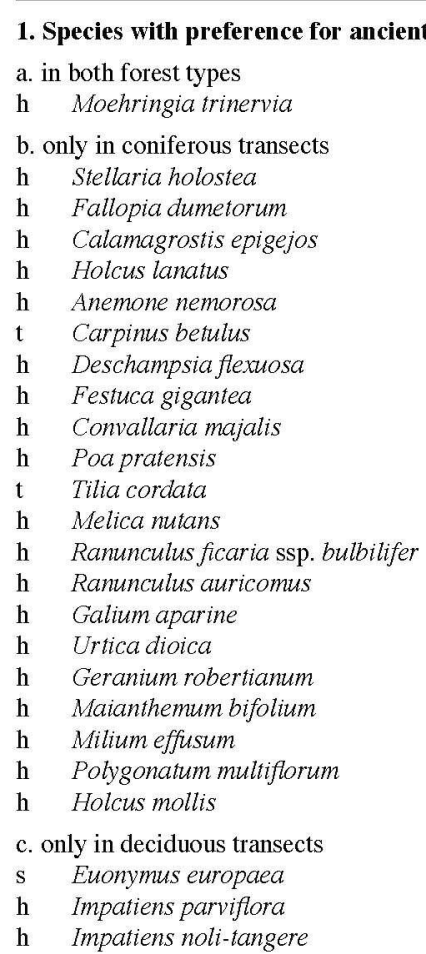

\begin{tabular}{|c|c|c|c|c|}
\hline 31.6 & 10.1 & 19.5 & 5.3 & 70 \\
\hline 57.0 & 11.1 & 9.8 & 19.5 & 116 \\
\hline 18.4 & 3.7 & 4.9 & 10.5 & 42 \\
\hline 21.1 & 3.7 & & 2.3 & 3 \\
\hline 9.6 & 1.6 & & & 17 \\
\hline 87.7 & 65.1 & 58.5 & 51.1 & 31 \\
\hline 26.3 & 15.3 & 7.3 & 6.8 & 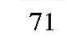 \\
\hline 36.8 & 13.8 & & 0.8 & 69 \\
\hline 14.0 & 5.3 & 14.6 & 27.8 & 69 \\
\hline 22.8 & 10.6 & & & 46 \\
\hline 17.5 & 5.3 & & & 30 \\
\hline 17.5 & 5.3 & & & 3 \\
\hline 14.0 & 5.3 & & & 2 \\
\hline 8.8 & 1.1 & 43.9 & 40.6 & \\
\hline 10.5 & 3.2 & 22.0 & 11.3 & 4 \\
\hline 28.1 & 7.9 & 36.6 & 34.6 & 10 \\
\hline 17.5 & 4.2 & 19.5 & 18.8 & \\
\hline 11.4 & 1.6 & 4.9 & 5.3 & 2 \\
\hline 25.4 & 11.1 & 9.8 & 6.0 & 6 \\
\hline 9.6 & 2.6 & & 0.8 & 17 \\
\hline 7.9 & 1.6 & 7.3 & 4.5 & 2 \\
\hline 8.8 & 2.1 & & & 1 . \\
\hline \multirow[t]{2}{*}{20.2} & \multirow[t]{3}{*}{24.3} & 14.6 & 0.8 & \\
\hline & & 82.9 & 58.6 & 11 \\
\hline 0.9 & & 46.3 & 24.1 & 5 \\
\hline 11.4 & 31.2 & 4.9 & 8.3 & 85 \\
\hline \multirow[t]{2}{*}{17.5} & 28.0 & 9.8 & 4.5 & 8 \\
\hline & 23.8 & & & \\
\hline \multirow[t]{2}{*}{0.9} & 7.4 & & 0.8 & 1 \\
\hline & 5.8 & & & \\
\hline 12.3 & 259 & & & \\
\hline
\end{tabular}

2. Species with preference for recent forests

a. only in coniferous transects

Lysimachia vulgaris

Viola reichenbachiana et riviniana

Pinus sylvestris

Taraxacum sect. Ruderalia

Molinia caerulea

Frangula almus 
Table 2, cont.

Forest type

C*

$\mathrm{C}$

$\mathrm{D}$

$\mathrm{D}$

$N$

b.) only in deciduous transects
h Glechoma hederacea
h Cirsium oleraceum
h Stellaria nemorum
h Dryopteris carthusiana

$\begin{array}{l:l:l}39.0 & 57.9 & 93 \\ 7.3 & 22.6 & 33 \\ 2.4 & 14.3 & 20 \\ & 11.3 & 30\end{array}$

3. Species without preference for ancient or recent forests

a. with preference for the coniferous forest type (drier sites)

\begin{tabular}{l|ccccc} 
with preference for the coniferous forest type (drier sites) & 78.1 & 84.7 & 12.2 & 12.8 & 271 \\
Acer pseudoplatanus & 26.3 & 33.9 & 2.4 & 2.3 & 98 \\
Quercus robur & 19.3 & 19.6 & 2.4 & 4.5 & 66 \\
Fagus sylvatica & 20.2 & 21.7 & & & 64 \\
Sorbus aucuparia ssp. aucuparia & 15.8 & 12.2 & & & 41 \\
Ulmus minor & 14.0 & 9.5 & & 0.8 & 35 \\
Cornus sanguinea & 9.6 & 10.1 & & & 30 \\
Epipactis helleborine & 10.5 & 7.4 & & 26
\end{tabular}

with preference for the deciduous forest type (moist sites)

Brachypodium sylvaticum

$14.0-21.2$

Deschampsia cespitosa

Mercurialis perennis

Circaea lutetiana

Geum urbanum

Angelica sylvestris

Oxalis acetosella

Aegopodium podagraria

Poa trivialis

Rubus fruticosus agg.

Fraxinus excelsior

Filipendula ulmaria

Agrostis stolonifera

Iris pseudacorus

$11.4 \quad 5.8$

$\begin{array}{ll}1.8 & 2.6\end{array}$

$5.3 \quad 3.7$

1.8

2.6

1.6

1.8

1.8

3.2

\begin{tabular}{|cc:c}
\hline 48.8 & 57.9 & 153 \\
56.1 & 67.7 & 137 \\
53.7 & 49.6 & 88 \\
36.6 & 38.3 & 73 \\
19.5 & 30.8 & 62 \\
19.5 & 30.1 & 48 \\
17.1 & 23.3 & 40 \\
19.5 & 19.5 & 37 \\
12.2 & 18.0 & 32 \\
12.2 & 14.3 & 28 \\
12.2 & 9.8 & 26 \\
9.8 & 15.8 & 25 \\
9.8 & 9.8 & 17 \\
7.3 & 3.0 & 7
\end{tabular}

c. Species without any clear preference

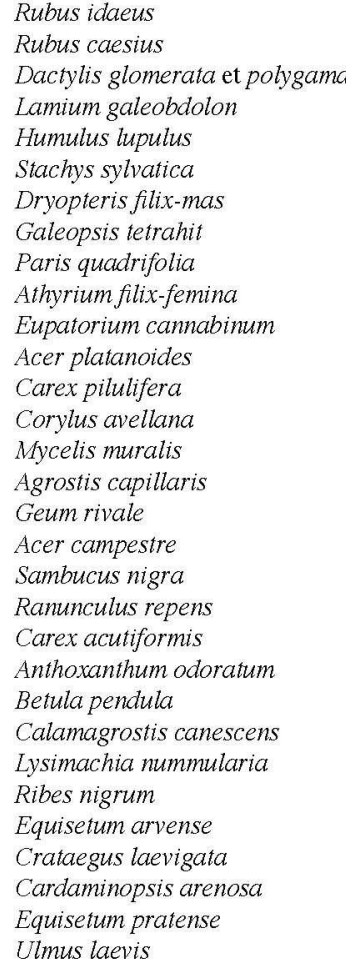

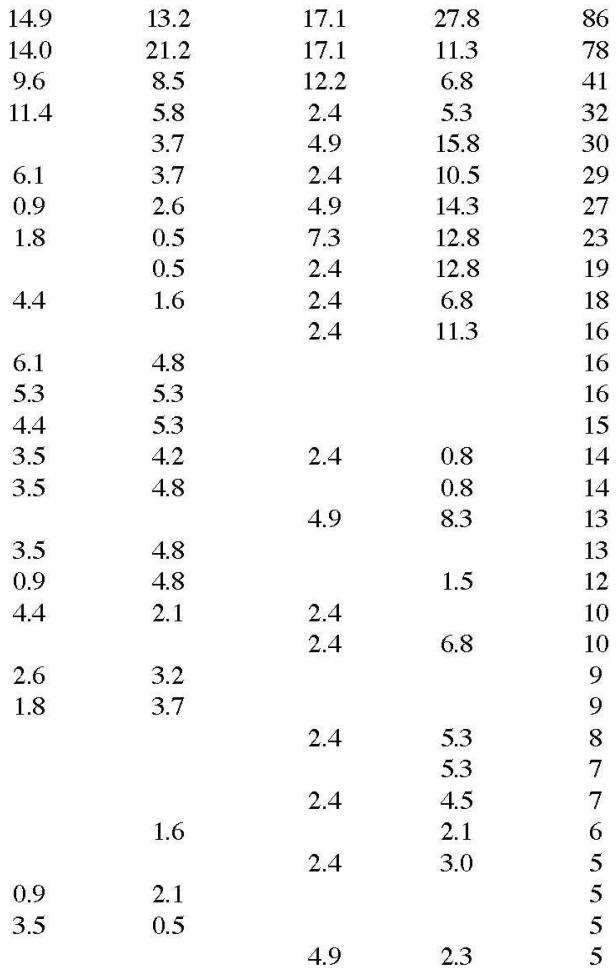


Table 3. Comparison of regression slopes (medians) in coniferous vs. deciduous stands. Slopes are derived from a linear regression of the total cover of species groups on the standardized distance from the ancient forest edge. Mann-Whitney $U$-test, $p$-values are designated as $* * *=p \leq 0.001 ; * *=p \leq 0.01 ; *=$ $p \leq 0.05 ;\left(^{*}\right)=p \leq 0.1 ; \mathrm{n} . \mathrm{s} .=$ not significant

\begin{tabular}{lr}
\hline Species groups & Coniferous vs. deciduous stands \\
\hline & \\
Trees and shrubs & -4.27 vs. -0.15 ** \\
Herbaceous species & -15.65 vs. -4.75 n.s. \\
Forest specialists (FS) & -6.03 vs. -18.58 n.s. \\
Generalists (GS) & -7.13 vs. 10.82 *** \\
FS - diaspore weight low & -0.20 vs. 2.18 n.s. \\
FS - diaspore weight high & -2.25 vs. -3.70 n.s. \\
FS - dispersal potential low & -3.23 vs. -16.83 n.s. \\
FS - dispersal potential high & -1.36 vs. $0.93 *$ \\
FS - clonal extension low & -0.80 vs. -1.15 n.s. \\
FS - clonal extension high & -3.38 vs. -18.48 n.s. \\
GS - diaspore weight low & -1.65 vs.. $5.49 * * *$ \\
GS - diaspore weight high & -0.75 vs. -0.87 n.s. \\
GS-dispersal potential low & -5.02 vs. $13.96 * * *$ \\
GS-dispersal potential high & -0.55 vs. 0.52 n.s. \\
GS-clonal extension low & -0.51 vs. $8.11 * * *$ \\
GS-clonal extension high & -4.79 vs. $2.07 *$ \\
\hline
\end{tabular}

\section{Colonization patterns of species groups}

In the coniferous sites, the cover values of species groups and trait-based subgroups always decreased from the ecotone to the recent stands, whereas some slopes were, unexpectedly, less steep compared to those of the deciduous sites (Tables 3 and 4). The few trees and shrubs in the deciduous ancient stands colonized the deciduous recent stands faster than the coniferous recent stands. The herbaceous species are also fast colonizers, but the result is not significant (Table 3). Differences in the median of slopes between trees/shrubs and herbaceous species were highly significant for the coniferous recent stands, but not for the deciduous recent stands despite an obvious trend (Table 3). The colonization of recent stands by forest specialists appears to be more hindered in deciduous than in coniferous sites, but is not significant (Table 3). In contrast, generalists show an increase of cover in the deciduous recent stands, whereas in coniferous recent stands all herbaceous species are strongly hindered in colonization (Table 3).

\section{Colonization patterns of trait-based subgroups}

Despite the steep regression slopes in the deciduous recent stands we found only relatively marginally significant results for the forest specialists compared with the generalists (Table 4) due to high variance in the data set. All but one comparison of trait-based subgroups for the generalists delivered (highly) significant results. Thus, generalists reflected much better the different pattern of colonization between coniferous and deciduous sites than the forest specialists. Surprisingly, the generalists with low dispersal potential and low clonal extension showed a distinctively higher increase in cover in the recent deciduous sites compared to the recent coniferous sites (Table 4). However, similarly to the results shown in Table 3 the forest specialists and generalists behave without exception as counterparts in the deciduous sites, but not in the coniferous sites.

\section{Discussion}

\section{Methodological problems}

Site effects on species colonization cannot fully be excluded at the regional level (cf. Verheyen et al. 2003) and even more so at the local level (cf. Utsugi et al. 2006). We spent much time locating forests with straight boundaries between ancient and recent stands, and without obvious disturbances by forest management. We tried to minimize site effects on colonization pattern by choosing ancient and recent stands with comparable site conditions according to the very fine scaled forest inventory (maps at scale 1:10 000, Table 1). Additionally, for the analysis of colonization pattern the use of functional groups is an approach which is more likely to reduce local site effects on species composition/colonization than analyzing single plant species (cf. Hérault et al. 2005).

\section{Preference of species for ancient vs recent stands}

Among the 25 species associated with ancient stands in the present study only nine (e.g. Anemone nemorosa and Maianthemum bifolium) are frequently mentioned as indicator species of ancient forests in Europe (Hermy et al. 1999). The preference of species for ancient forests is of ten explained by their lack of effective seed dispersal (Hermy et al. 1999). Indeed, the diaspores of many forest specialists have no features facilitating long-distance dispersal (Klotz et al. 2002) and species colonize recent forests slowly or are absent even after several decades or centuries (Verheyen et al. 2003). However, species' preference for ancient forests is nearly restricted to 
Table 4. Comparison of regression slopes (medians) of species groups in coniferous vs. deciduous stands. Slopes are from a linear regression of the total cover of species groups on the standardized distance from the ancient forest edge. Mann-Whitney $U$-test, $p$-values are designated as $*^{*}=p \leq 0.001 ; *^{*}=p \leq 0.01 ; *=p \leq 0.05 ;\left(^{*}\right)=p \leq 0.1 ;$ n.s. = not significant.

\begin{tabular}{lrr}
\hline Species groups & Coniferous stands & Deciduous stands \\
\hline Trees and shrubs vs. herbaceous species & -4.27 vs. $-15.65 * * *$ & -0.15 vs. -4.75 n.s. \\
Forest specialists (FS) vs. generalists (GS) & -6.03 vs. -7.13 n.s. & -18.58 vs. $10.82 *$ \\
FS: diaspore weight low vs. diaspore weight high & -0.20 vs. -2.25 n.s. & 2.18 vs. -3.70 n.s. \\
FS: dispersal potential low vs. dispersal potential high & -3.23 vs. $-1.36 *$ & -16.83 vs. 0.93 n.s. \\
FS: clonal extension low vs. clonal extension high & -0.80 vs. $-3.38 *$ & -1.15 vs. $-18.48(*)$ \\
GS: diaspore weight low vs. diaspore weight high & -1.65 vs. -0.75 n.s. & 5.49 vs. $-0.87 * *$ \\
GS: dispersal potential low vs. dispersal potential high & -5.02 vs. -0.55 *** & 13.96 vs. 0.52 n.s. \\
GS: clonal extension low vs. clonal extension high & -0.51 vs. $-4.79 * * *$ & 8.11 vs. $2.07 *$ \\
\hline
\end{tabular}

the coniferous transects which can be explained by site conditions. In the ancient deciduous stands mull humus prevails, whereas the recent coniferous stands are dominated by moder. Only three species are ancient indicator species in the deciduous transects, which is not surprising for two reasons. First, several forest species have been observed in meadows or extensively pastured meadows, e.g. A. nemorosa and $M$. bifolium (Wulf 2004). It is possible that they have survived as small populations over a long time in the former moist grassland (Graae 2000; Flinn \& Vellend 2005). Second, the mean age of the deciduous recent stands is $\mathbf{5 4}$ years, and thus 24 years older than the coniferous recent stands. There was simply more time to colonize the deciduous recent plots (Brunet \& von Oheimb 1998). The preference of certain species for recent stands in the coniferous transects is possibly caused by a steeper environmental gradient between ancient and recent plots compared to the deciduous transects. The preference of $P$. sylvestris is due to enhanced seed rain, whereas the preference of other species could mainly be explained with differences in light conditions and humus types.

\section{Preference of species for coniferous vs deciduous sites}

Among the 14 species occurring significantly more often in recent part of the coniferous transects, eight are trees and shrubs $(67 \%)$. This may be caused by the high light flux to the ground and the acidic humus type 'moder', which provides optimal conditions for their regeneration (Hofmann 1964). The herbaceous species being more frequent in the deciduous transects are mainly $(65 \%)$ indicators of moist soils. Thus, they benefit from slightly moister soils in the deciduous stands (Table 1).

\section{Colonization patterns}

The total number of species, number of species in all species groups and in trait subgroups are comparable (App. 1). This confirmed our assumption that many forest specialists and generalists can potentially occur in coniferous stands with a good nutrient availability and at least moderate water availability. Investigations in NE Germany (Hofmann 1964) revealed that several of our species regularly occur in Pinus stands, e.g. A. nemoros $a$ and $S$. holostea. The decreasing cover values of most of the species groups_with distance from the ecotone can be explained by dispersal limitation during the colonization of recent forests (Verheyen et al. 2003). However, recovery of Pinus stands can be assumed to be fast since the stands are only 30 years old.

\section{Woody vs. herbaceous species}

The retarded migration of plant species into recent stands was also observed by, for example, Brunet \& von Oheimb (1998) and Bossuyt et al. (1999). However, the relatively flat regression lines of the woody species proved their ability to effectively colonize coniferous and deciduous recent stands. For most of the tree species, this can be explained by their high wind dispersal potential due to low terminal velocities in combination with high exposition height of their diaspores (Tackenberg 2001). Since most of the shrub and some of the tree species produce fruits attractive to birds or mammals, their seeds are also easily dispersed (Schaumann \& Heinken 2002). The positive steep slopes of generalists in the deciduous stands are not unexpected for several reasons. The generalists (mostly grasses) produce many small seeds, and some of them are highly competitive due to their long stolons or rhizomes. These traits enable them to occupy large areas after initial colonization of forests with a less dense canopy, and to reach quickly high cover values (Ellenberg 1988). All recent stands have been formerly used as grassland which enables the establishment and survival of many generalists as adult plants (Wulf 2004). Finally, there may be simply more space for generalists due to the reduced number and cover of forest specialists. 


\section{Forest specialists vs. generalists}

In the deciduous transects the forest specialists with low dispersal potential may possibly compensate the lack of adaptations to long-distance dispersal with extensive clonal growth. However, the steep negative slopes indicated that dispersal limitation could not be compensated with high clonal extension. This agrees with the prediction that forest specialists with low colonization potential are dispersal limited. The high cover of grasses (significantly negative correlation between cover of graminoids and forbs: -0.431 , $P<0.001)$ has obviously negative effects on recruitment and establishment of most forest specialists in recent stands (Sydes \& Grime 1981).

There may be no significant difference in colonization pattern between short- and long-distance dispersers among the generalists subgroup, because species may come from different directions (ancient stands or open landscape) or may have been present prior to afforestation (Honnay et al. 1999; Wulf 2004). The same is true for the species with low and high clonal extension which are more abundant far away from the ancient stands (cf. Brunet \& von Oheimb 1998). In general, the trends for forest specialists in coniferous transects are similar to those of the deciduous sites, but there is a clear significance for the forest specialists/dispersal potential and clonal extension-subgroups. The distinctively flat slopes indicated that migration of species into coniferous recent stands is more accelerated than into deciduous recent stands. This is an unexpected result, and the most convincing explanation is that the litter of Pinus is a much weaker barrier for colonization than a dense grass cover.

\section{Implications for regeneration of recent stands}

Our own, and previous studies in Poland (Dzwonko 2001), have demonstrated that several forest species are able to colonize Pinus plantations adjoining deciduous forests when these were established on soils with good nutrient supply and at least moderate water balance. Similar results were found for Picea abies stands on base-rich soils in a landscape with high forest connectivity (Hérault et al. 2005). In the context of enhancing species diversity, forestry in the European Union aims to increase the proportions of mixed or deciduous forests (Spiecker 2003; Wulf 2003). Our results suggest that conversion of coniferous into deciduous forests is preferably conducted on sites with good nutrient and water supply that adjoin ancient deciduous forests, the latter serving as source for forest specialists. From our results we can conclude that it is not necessary to convert smaller stands with nearby diaspore sources by means of planting trees, because many trees and shrubs colonize the coniferous stands quicker than the herbaceous species. Thus, management (e.g. cost-intensive plantations) could be reduced to a large extent which may be attractive from an economical point of view. From the comparison with deciduous recent stands we can appreciate that the former land use plays an important role for colonization patterns of forest and other species. Deciduous stands do not guarantee higher richness of forest specialists. If recent stands are established on former grasslands, one major management task must be suppressing the dense cover of grasses in order to facilitate colonization of forest species. This can be achieved by means of the development of tree species forming a dense canopy which negatively affect light demanding grass species, but increases the chance of colonization by shade-tolerant forest specialists (cf. Hérault et al. 2005).

Acknowledgements. The research was supported through basic funding of the research institution by the Federal Ministry of Food, Agriculture and Consumer Protection of Germany (BMELV, Bonn, Germany) and by the Ministry for Rural Development, Environment and Consumer Protection of Brandenburg (MLUV, Potsdam, Germany). We thank Ute Jahn for technical assistance, Astrid Jahr-Trautwein and Astrid Günther for field assistance, Annette Kolb for proof reading and three anonymous reviewers for their helpful comments. 


\section{References}

Anon. 2003. SPSS Base 12.0. SPSS, Chicago, IL, US.

Anon. 2006. World Reference Base for Soil Resources 2006. World Soil Resources Reports No. 103. FAO, Rome, IT. (see link: ftp://ftp.fao.org/agl/agll/docs/wsrr103e.pdf)

Augusto, L., Bonnaud, P. \& Ranger, J. 1998. Impact of tree species on forest soil acidification. Forest Ecology and Management 105: 67-78.

Bossuyt, B., Hermy, M. \& Deckers, J. 1999. Migration of herbaceous plant species across ancient-recent forest ecotones in central Belgium. Journal of Ecology 87: 628-638.

Brunet, J. \& von Oheimb, G. 1998. Migration of vascular plants to secondary woodlands in southern Sweden. Journal of Ecology 86: 429-438.

Dzwonko, Z. 2001. Migration of vascular plant species to a recent wood adjoining ancient woodland. Acta Societatis Botanicorum Poloniae 70: 71-77.

Ehrlén, J. \& Eriksson, O. 1993. Toxicity - nonadaptive trait? Oikos 66: 107-113.

Ellenberg, H. 1988. Vegetation ecology of Central Europe. Cambridge University Press, Cambridge, UK.

Eriksson, O. 1995. Seedling recruitment in deciduous forest herbs: the effects of litter, soil chemistry and seed bank. Flora 190: 65-70.

Ewald, J. 2000. The influence of coniferous canopies on understory vegetation and soils in mountain forests of the northern calcareous Alps. Applied Vegetation Science 3: 123-134.

Flinn, K.M. \& Vellend, M. 2005. Recovery of forest plant communities in post-agricultural landscapes. Frontiers in Ecology and the Environment 3: 243-250.

Graae, B.J. 2000. The effect of landscape fragmentation and forest continuity on forest floor species in two regions of Denmark. Journal of Vegetation Science 11: 881-892.

Heinken, T. \& Raudnitschka, D. 2002. Do wild ungulates contribute to the dispersal of vascular plants in Central European forests by epizoochory? A case study in NE Germany. Forstwissenschaftliches Centralblatt 121: 179-194.

Heinken, T., Hanspach, H. \& Schaumann, F. 2001. Welche Rolle spielt die endozoochore Ausbreitung von Pflanzen durch wildlebende Säugetiere? Untersuchungen in zwei brandenburgischen Waldgebieten. Hercynia 34: 237-259.

Hérault, B., Honnay, O. \& Thoen, D. 2005. Evaluation of the ecological restoration potential of plant communities in Norway spruce plantations using a life-trait based approach. Journal of Applied Ecology 42: 536-545.

Hermy, M. \& Stieperaere, H. 1981. An indirect gradient analysis of the ecological relationship between ancient and recent riverine woodlands to the south of Bruges (Flanders, Belgium). Vegetatio 44: 43-49.

Hermy, M., Honnay, O., Firbank, L., Grashof-Bokdam, C. \& Lawesson, J.E. 1999. An ecological comparison between ancient and other forest plant species of Europe, and the implications for forest conservation. Biological
Conservation 91: 9-22.

Hofmann, G. 1964. Kiefernforstgesellschaften und natürliche Kiefernwälder im östlichen Brandenburg. I. Kiefernforstgesellschaften. Archiv für Forstwesen 13: 641-664.

Hofmann, G. \& Pommer, U. 2004. Das natürliche Waldbild Brandenburgs. AFZ-Der Wald 22: 1211-1215.

Honnay, O., Hermy, M. \& Coppin, P. 1999. Impact of habitat quality on forest plant species colonization. Forest Ecology and Management 115: 157-170.

Klimeš, L., Klimešová, J., Hendriks, R. \& van Groenendael, J. 1997. Clonal plant architecture: a comparative analysis of form and function. In: de Kroon, H. \& van Groenendael, J. (eds.) The ecology and evolution of clonal plants, pp. 1-29. Backhuys, Leiden, NL.

Klotz, S., Kühn, I. \& Durka, W. 2002. BIOLFLOR - Eine Datenbank mit biologisch-ökologischen Merkmalen zur Flora von Deutschland. Schriftenreihe für Vegetationskunde 38: 1-334.

Kollmann, J. 1994. Ausbreitungsökologie endozoochorer Gehölzarten. Veröffentlichungen des Projektes Angewandte Ökologie 9: 1-212.

Mather, A. 2000. Afforestation: Progress, trends and policies. In: Weber, N. (ed.) NEWFOR - New forests for Europe: Afforestation at the turn of the century, pp. 11-19. EFI Proceedings No. 35. European Forest Institute (EFI), Saarijärvi, FI.

Müller-Schneider, P. 1986. Verbreitungsbiologie der Blütenpflanzen Graubündens. Veröffentlichungen des Geobotanischen Institutes der Eidgenossischen Technischen Hochschule Stiftung Rübel 85: 1-263.

Nagaike, T., Kamitani, T. \& Nakashizuka, T. 2005. Effects of different forest management systems on plant species diversity in a Fagus crenata forested landscape of central Japan. Canadian Journal of Forest Research 35: $2832-2840$

Nyland, R.D. 2003. Even- to uneven-aged: the challenges of conversion. Forest Ecology and Management 172: 291-300.

Peterken, G.F. 1993. Woodland conservation and management. 2nd. ed. Chapman \& Hall, London, UK.

Schaumann, F. \& Heinken, T. 2002. Endozoochorous seed dispersal by martens (Martes foina, Martes martes) in two woodland habitats. Flora 197: 370-378.

Schmidt, M., Ewald, J., Fischer, A., von Oheimb, G., Kriebitzsch, W.U., Ellenberg, H. \& Schmidt, W. 2003. Liste der in Deutschland typi schen Waldgefäßpflanzen. Mitteilungen der Bundesforschungsanstalt für Forstund Holzwirtschaft 212: 1-34.

Schmidt, M., Sommer, K., Kriebitzsch, W.U., Ellenberg, H. \& von Oheimb, G. 2004. Dispersal of vascular plants by game in Northern Germany. Part I: Roe deer (Capreolus capreolus) and Wild Boar (Sus scrofa). European Journal of Forest Research 123: 167-176.

Spiecker, H. 2003. Silvicultural management in maintaining biodiversity and resistance of forests in Europetemperate zone. Journal of Environmental Management 67: 55-65.

Stöcklin, J. 1992. Umwelt, Morphologie und Wachstum 
klonaler Pflanzen. Botanica Helvetica 102: 3-21.

Sydes, C. \& Grime, J.P. 1981. Effects of tree leaf litter on herbaceous vegetation in deciduous woodland. I. Field investigations. Journal of Ecology 69: 237-248.

Tackenberg, O. 2001. Methoden zur Bewertung gradueller Unterschiede des Ausbreitungspotentials von Pflanzenarten. Dissertationes Botanicae 347: 1-138.

Utsugi, E., Kanno, H., Ueno, N. et al. 2006. Hardwood recruitment into conifer plantations in Japan: Effects of thinning and distance from neighbouring hardwood forests. Forest Ecology and Management 237: 15-28.
Verheyen, K., Honnay, O., Motzkin, G., Hermy, M. \& Foster, D.R. 2003. Response of forest plant species to land-use change: a life-history trait-based approach. Journal of Ecology 91: 563-577.

von Oheimb, G., Schmidt, M., Kriebitzsch, W.U. \& Ellenberg, H. 2005. Dispersal of vascular plants by game in Northern Germany. Part II: Red deer (Cervus elaphus). European Journal of Forest Research 124: 55-65.

Wisskirchen, R. \& Haeupler, H. 1998. Standardliste der Farnund Blütenpflanzen Deutschlands. Ulmer, Stuttgart, DE.

Wulf, M. 2003. Forest policy in the EU and its influence on the plant diversity of woodlands. Journal of Environmental Management 67: 15-25.

Wulf, M. 2004. Species richness of afforestations with different former use and habitat continuity. Forest Ecology and Management 195: 191-204.

Received 8 May 2007; Accepted 5 November 2007; Co-ordinating Editor: M. Chytrý.

For Apps. 1-2, see below (online version) also available at JVS/AVS Electronic Archives; www.opuluspress.sel 